\title{
Factors Influencing the Intention to Use the Online Face Mask Information System during the COVID-19 Pandemic
}

\author{
Yi-Horng Lai ${ }^{1 \star}$ (1) \\ ${ }^{1}$ Department of Health Care Administration, Asia Eastern University of Science and Technology, New Taipei City, TAIWAN
} *Corresponding Author: FL006@mail.aeust.edu.tw

Citation: Lai Y-H. Factors Influencing the Intention to Use the Online Face Mask Information System during the COVID-19 Pandemic. Electron J Gen Med. 2022;19(2):em348. https://doi.org/10.29333/ejgm/11547

ARTICLE INFO
Received: 5 Oct. 2021
Accepted: 22 Dec. 2021

Accepted: 22 Dec. 2021

\begin{abstract}
Background: People believe that the mandate of face mask-wearing in public places is one of the keys to success in preventing the COVID-19 spread. This study aimed to examine how health information sites' information quality, system quality, and service quality lead to user satisfaction and the acceptance of the face mask mandate in public places.

Method: The data this study collected was from 303 users of the online face mask information system in Taiwan during the COVID-19 pandemic. The statistical analysis method employed was to apply Partial Least Square (PLS) to test all of the hypotheses in this study.

Results: The results of this study have shown that first, the information quality, system quality, and ser-vice quality would have a direct positive impact on the intention to use and user satisfaction. Second, the acceptance of the face mask mandate in public places would be affected by perceived threat of COVID-19, the intention to use, and user satisfaction. Third, system quality and service quality play an important role in these three qualities of the information system.

Conclusions: In order to enhance the acceptance of the face mask mandate, the public health department should make good use of information systems so that people can purchase face masks easily.

Keywords: COVID-19, online face mask information system, DeLone and McLean IS success model, perceived threat
\end{abstract}

\section{INTRODUCTION}

The COVID-19 virus first emerged in the end of 2019 and since then has spread across the world. The World Health Organization (WHO) declared on March 11, 2020 that the coronavirus outbreak is a "global pandemic" which is generally defined as an illness that spreads far and wide throughout the world [1]. According to the WHO's weekly up-date, there have been 120,383,919 confirmed cases of COVID-19, including 2,664,386 deaths as of March 2021 [2]. The first case in Taiwan was confirmed in a 50-year-old woman who had just returned to Taiwan from China on January 21, 2020. Since then, there have been 998 confirmed cases of COVID-19, including 10 deaths as of March 2021 [3].

People believe that the mandate of face mask-wearing in public places is one of the keys to success in preventing the COVID-19 spread [4,5], and many reports [4] indicate that the intention to wear face masks would be increased with the application of information technology during influenza-like illness. Unfortunately, it has not been guided by research and hence it is less possible to examine this health behavior in a more systematic way. This study investigated the factors influencing the ordering of face masks with the online system in Taiwan during the COVID-19 pandemic, and the application of information technology and the acceptance of the face mask mandate in public places. Since the DeLone and McLean Model of information systems success (D\&M IS success model) has been commonly used for examining success factors of information systems, it was employed as an overarching theoretical framework in this study. Findings from this study can inform future prevention initiatives when new infectious diseases emerge.

\section{Effectiveness of Face Mask Wearing in Preventing COVID-} 19

In the face of this new infectious disease, prevention strategies such as face mask wearing, social distancing, selfisolating, and vaccination have been recommended by public health experts [6]. Among them, face mask wearing, which is generally perceived as typical daily behavior, has been found to be more readily accepted and less constrained by limitations on supplies and effectiveness, compared with other preventive measures [7].

In order to diminish the crowds of people lining up in front of drug stores and pharmacies, an online mask distribution system was launched on March 12, 2020 in Taiwan (Figure 1). To preorder face masks, people may enter the mask distribution system (The Name-Based Rationing System for Face Masks) using their national health insurance cards. A 


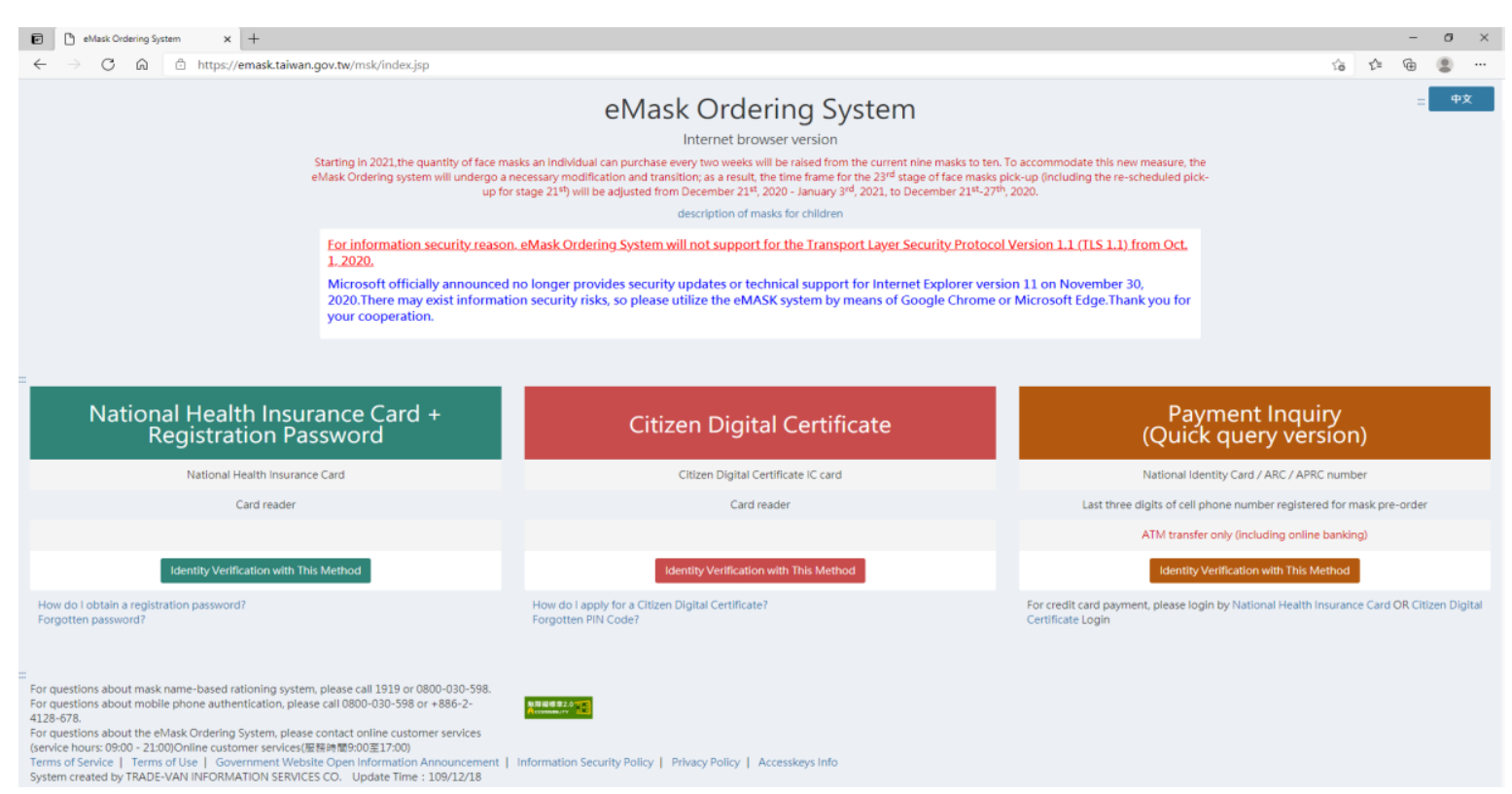

Figure 1. The online face mask information system (https://emask.taiwan.gov.tw/msk/index.jsp)

notification will be sent if an order is successful, and after payment, the face masks will be available to pick up at convenience stores. This system helps to simplify the process of buying masks during time of the coronavirus epidemic [8].

\section{DeLone and McLean IS Success Model}

DeLone and Mclean summarized previous studies discussing efficacy as a dependent variable in an information system. They attempted to bring some awareness and structure to the dependent variable of IS success factors in IS research. For the application of IS success's conceptualization and operationalization, they proposed a model referred to as the "DeLone and McLean IS Success Model" (D\&M IS success model) [9]. They believe that system quality, information quality, and service quality affect the intention to use the system and user satisfaction, and the extent of system use affects user satisfaction. D\&M IS success model brought a wideranging discussion due to its various dimensions in assessing an information system [10]. Thus, it deeply influences researchers' views of a successful information system.

\section{Perceived Threat}

Some existing models explore the factors influencing people's preventative health behaviors, such as the health belief model (HBM) [11]. It has been used to examine both behavioral intentions and performed behavior across prevention behaviors including self-health management, epidemic prevention measures, and vaccinations. The HBM model included perceived threat of diseases (perceived susceptibility and severity) and perceived benefits and barriers of the preventative behavior. Perceived susceptibility refers to the subjective assessment of risks of contracting a condition. Perceived seriousness of a condition may include broader and more complex implications because of the impact on the job, family life and social relations.

\section{MATERIALS AND METHOD}

The online face mask information system success model (Figure 2) used in this study is modified from D\&M IS success model [9] and HBM [11]. The primary benefit of the government's efforts to build the online face mask information system is that it enhances people's acceptance of the maskwearing mandate in public places.

To find out the relationships among information quality (INFQ), system quality (SYSQ), service quality (SERQ), and user's intention to use an online system, the use of online health information system was investigated [12] and learned that INFQ, SYSQ, and SERQ are positively correlated with the user's intention to use the system (Hypotheses 1, 2, and 3). And the study [9] has pointed out that INFQ, SYSQ, and SERQ positively influence user satisfaction. Similar conclusions have been drawn from studies of online health information system evaluation [13] (Hypothesis 4, 5, and 6)- the studies on satisfaction have pointed out users with a higher level of satisfaction tend to have a stronger in-tention to reuse and recommend the system $[10,13]$. In other words, when the user satisfaction is enhanced, the intention to use the system is also increased (Hypothesis 7). In the discussion of the relationships among use, user satisfaction and benefits, the studies claimed that use and user satisfaction have direct effects on the benefit (Hypothesis 8 and 9) $[9,13]$. Based on HBM [11], intention of preventa-tive behaviors (intention to use an online system and the acceptance of face mask mandate in the study) is affected by perceived threat of the disease (Hypothesis 10 and 11).

\section{Measures}

INFQ measurement in this study is modified from the study [14]. It is measured by assessing four items: precision, comprehensiveness, intelligibility, and up-to-dateness. The measurement of SYSQ in this study is developed by Venkateshand and Bala's Technology acceptance model 3 [15]. SYSQ in this study is a two-level inner variable which is combined with perceived usefulness and perceived ease of use [15]. In the questionnaire developed by [16], SERQ is measured by five dimensions. However, because of the nature of the online information system, SERQ is measured only with reliability and assurance in this study. The questionnaire for user satisfaction used in this study is adapted from [17]. The measurement of perceived threat consists of three items which are adapted from [18]. 


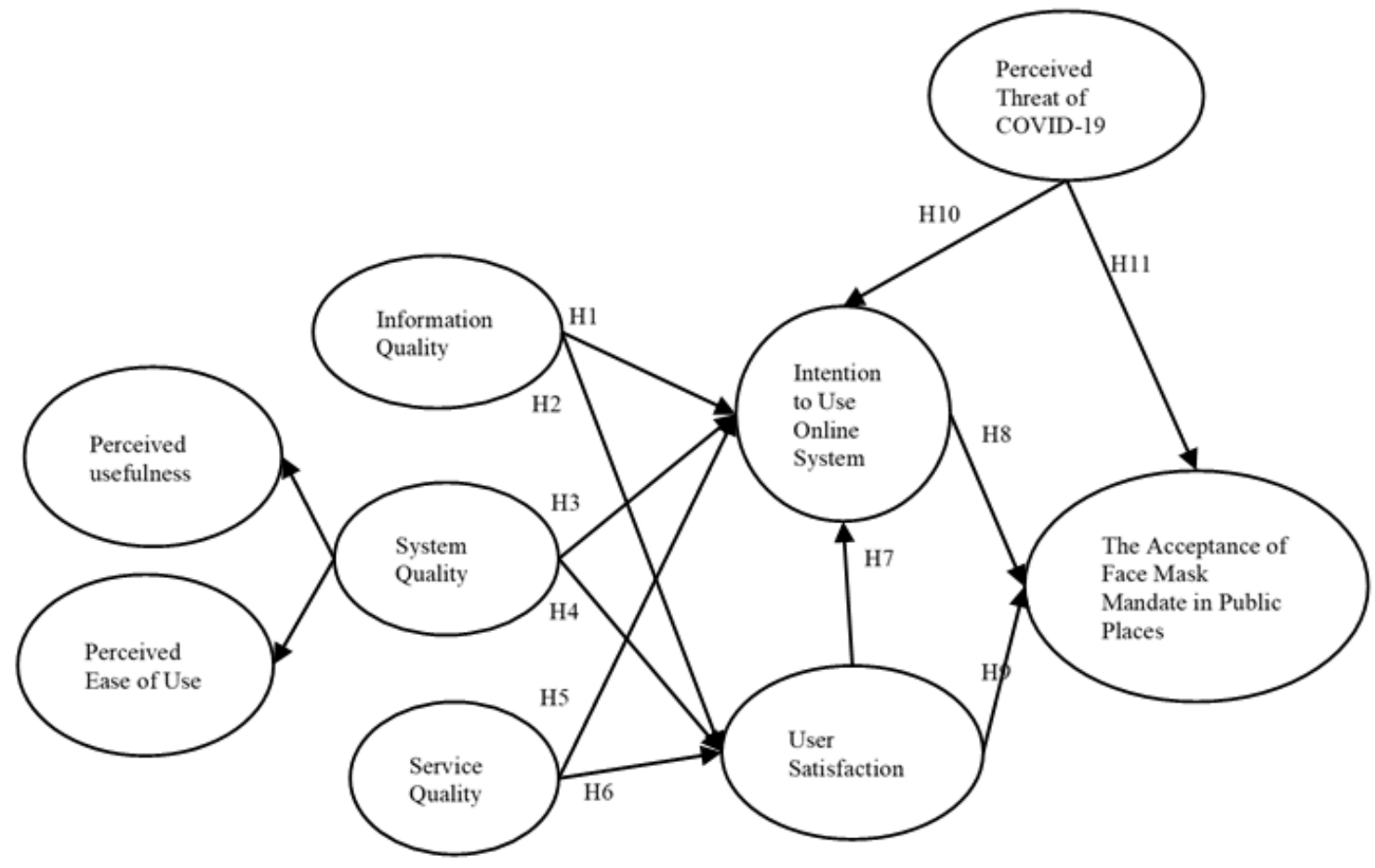

Figure 2. The research model

Table 1. Demographic information

\begin{tabular}{cccc}
\hline Items & Categories & Frequency & Percentage (\%) \\
\hline \multirow{2}{*}{ Gender } & Male & 138 & 45.54 \\
\cline { 2 - 4 } & Female & 165 & 54.45 \\
\cline { 2 - 4 } & $0 \sim 19$ & 24 & 7.92 \\
\cline { 2 - 4 } Age & $20 \sim 29$ & 172 & 56.77 \\
\cline { 2 - 4 } & $30 \sim 39$ & 60 & 19.80 \\
\cline { 2 - 4 } & $40 \sim 49$ & 28 & 9.24 \\
\cline { 2 - 4 } & $50 \sim$ & 19 & 6.27 \\
\cline { 2 - 4 } Education & High school & 40 & 13.20 \\
\cline { 2 - 4 } & College & 207 & 68.32 \\
\cline { 2 - 4 } & Master's & 56 & 18.48 \\
\hline Total & & 303 & 100.00 \\
\hline
\end{tabular}

All of the items in this study are rated on the Likert-scale from 1 (strongly disagree) to 7 (strongly agree). The survey was conducted both online and in hard-copy. Questions on the survey were closed-ended and participation was voluntary. Data was collected from July 2020 to October 2020.

\section{Data Analysis}

In this study, the data was analyzed by partial least squares path modeling (PLS-PM) using SmartPLS 3.3.3 [19]. The research model in this study has both formative and reflective constructs. Therefore, PLS-PM is appropriate for data analysis for this study because it allows simultaneous assessment of structural model parameters and path coefficients. Moreover, PLS-PM allows both reflective and formative constructs to be examined together [20].

\section{RESULTS}

Table 1 shows the socio-demographic characteristics of the 303 respondents. As shown in Table 1, 165 of the respondents were female (54.45\%), and 138 (45.54\%) were male. $7.92 \%$ of the respondents were aged $0-19,56.77 \%$ were
Table 2. Data summary

\begin{tabular}{ccccccccc}
\hline \multicolumn{2}{l}{ Construct Items } & Mean & S.E. & $\begin{array}{c}\text { Cronbach's } \\
\text { alpha }\end{array}$ & C.R. & AVE & R2 \\
\hline INFQ & 5 & 5.78 & 0.936 & 0.917 & 0.938 & 0.754 & - \\
\hline SYSQ & 5 & 5.81 & 0.954 & 0.901 & 0.927 & 0.850 & - \\
\hline SERQ & 3 & 5.67 & 1.025 & 0.866 & 0.919 & 0.790 & - \\
\hline INTU & 3 & 5.74 & 1.034 & 0.924 & 0.953 & 0.870 & 0.834 \\
\hline SATI $^{\star}$ & 3 & 5.70 & 1.048 & 0.852 & - & - & 0.785 \\
\hline PTH & 3 & 5.51 & 1.096 & 0.770 & 0.868 & 0.690 & - \\
\hline ACCM & 3 & 5.48 & 1.240 & 0.928 & 0.952 & 0.868 & 0.804 \\
\hline
\end{tabular}

*User Satisfaction (SATI) are formative variables

aged $20-29,9.80 \%$ were aged $30-39,9.24 \%$ were aged $40-49$ and $6.27 \%$ were aged 50 and above. As for education level, $13.20 \%$ had high school diplomas, $68.32 \%$ had college degrees and $18.48 \%$ had Master's degrees.

\section{Measurement Model}

Data summary of this study can be found in Table 2 . The Cronbach's alpha analysis was used to measure the reliability of the measurement. All measurement scales reveal that acceptable reliability coefficients range from the lowest coefficient of 0.785 to the highest of 0.834 . The Cronbach's alpha of all items are greater than 0.7 and are within the acceptable range. It was shown that convergent validity can be checked by utilizing composite reliability $(\mathrm{CR})$ and variance extracted by constructs (AVE) [21]. The AVE value of each construct should be higher than 0.5 , and the $C R$ value of each construct should be higher than 0.7 . Perceived threat has the lowest CR value (0.868) (Table 2).

In Figure 3, it is obvious that these factor loadings are higher than 0.7. In Table 3, we can see that in the cross-loading matrix of the items in each construct, the loading of all items in each construct is higher than that in other constructs. Therefore, it can be shown from the two indicators that the questionnaire designed in the study has a certain level of discriminant validity. 


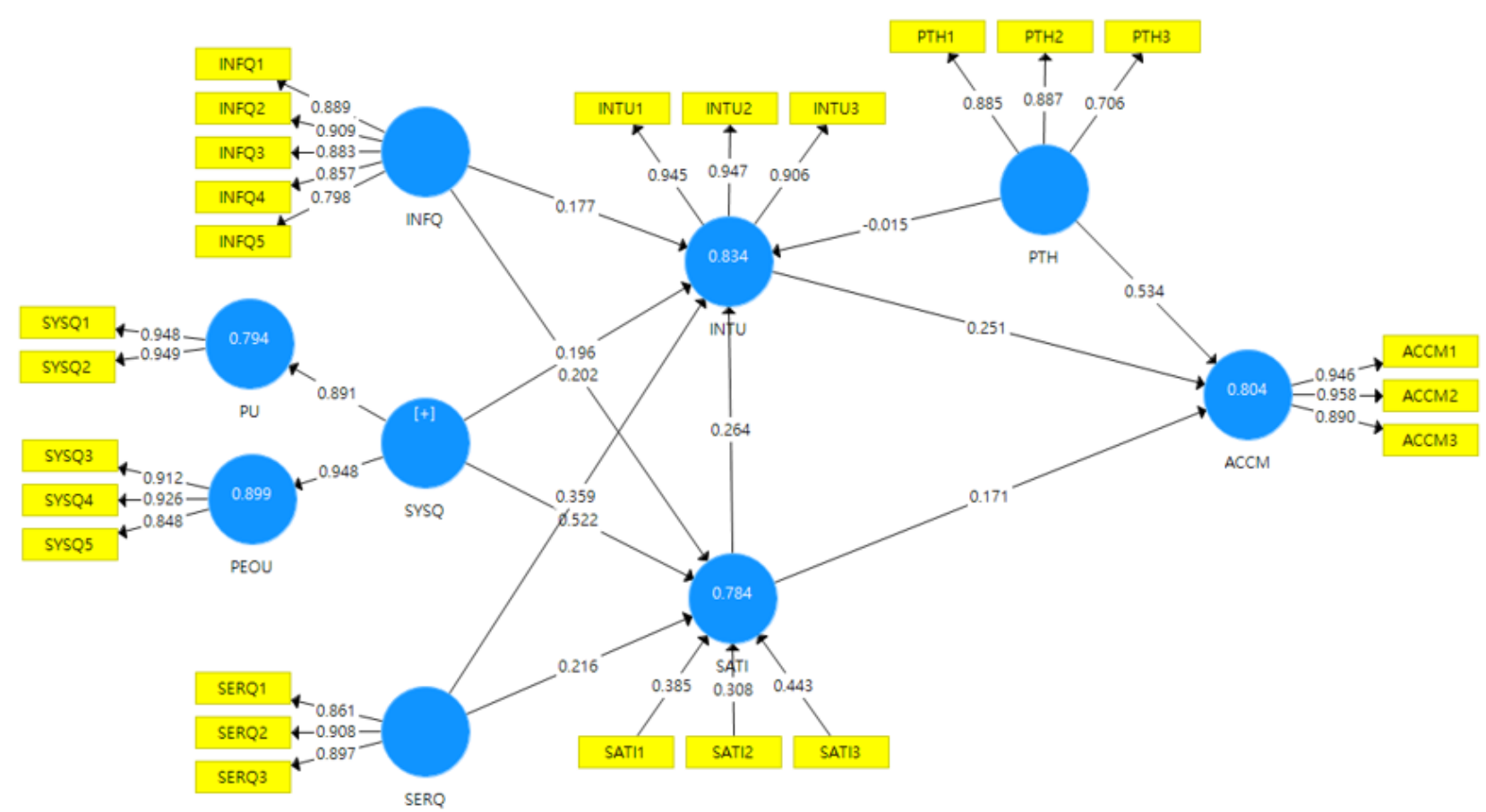

Figure 3. Research results

Table 3. Cross loading of items in each construct in the study

\begin{tabular}{lccccccc}
\hline & ACCM $^{1}$ & INFQ $^{2}$ & INTU & PTH $^{3}$ & SATI $^{4}$ & SERQ & SYSQ \\
\hline ACCM1 & 0.946 & 0.729 & 0.761 & 0.829 & 0.785 & 0.716 & 0.728 \\
\hline ACCM2 & 0.958 & 0.728 & 0.784 & 0.837 & 0.796 & 0.725 & 0.763 \\
\hline ACCM3 & 0.890 & 0.686 & 0.680 & 0.749 & 0.735 & 0.635 & 0.737 \\
\hline INFQ1 & 0.678 & 0.889 & 0.754 & 0.656 & 0.736 & 0.729 & 0.749 \\
\hline INFQ2 & 0.733 & 0.909 & 0.782 & 0.689 & 0.755 & 0.740 & 0.792 \\
\hline INFQ3 & 0.702 & 0.883 & 0.739 & 0.707 & 0.750 & 0.703 & 0.747 \\
\hline INFQ4 & 0.625 & 0.857 & 0.728 & 0.614 & 0.670 & 0.752 & 0.702 \\
\hline INFQ5 & 0.580 & 0.798 & 0.628 & 0.593 & 0.609 & 0.648 & 0.619 \\
\hline INTU1 & 0.766 & 0.806 & 0.945 & 0.712 & 0.808 & 0.786 & 0.820 \\
\hline INTU2 & 0.770 & 0.797 & 0.947 & 0.730 & 0.794 & 0.818 & 0.811 \\
\hline INTU3 & 0.694 & 0.744 & 0.906 & 0.661 & 0.773 & 0.797 & 0.726 \\
\hline PTH1 & 0.781 & 0.648 & 0.657 & 0.885 & 0.702 & 0.628 & 0.714 \\
\hline PTH2 & 0.805 & 0.638 & 0.619 & 0.887 & 0.699 & 0.597 & 0.687 \\
\hline PTH3 & 0.546 & 0.593 & 0.602 & 0.706 & 0.685 & 0.575 & 0.570 \\
\hline SATI1 & 0.743 & 0.700 & 0.758 & 0.759 & 0.894 & 0.705 & 0.779 \\
\hline SATI2 & 0.686 & 0.743 & 0.721 & 0.702 & 0.841 & 0.682 & 0.703 \\
\hline SATI3 & 0.749 & 0.712 & 0.755 & 0.734 & 0.896 & 0.705 & 0.779 \\
\hline SERQ1 & 0.661 & 0.792 & 0.771 & 0.658 & 0.714 & 0.861 & 0.742 \\
\hline SERQ2 & 0.671 & 0.739 & 0.770 & 0.654 & 0.724 & 0.908 & 0.698 \\
\hline SERQ3 & 0.652 & 0.662 & 0.745 & 0.607 & 0.677 & 0.897 & 0.671 \\
\hline SYSQ1 & 0.595 & 0.640 & 0.654 & 0.625 & 0.666 & 0.575 & 0.833 \\
\hline SYSQ2 & 0.626 & 0.688 & 0.687 & 0.648 & 0.738 & 0.630 & 0.845 \\
\hline SYSQ3 & 0.680 & 0.686 & 0.716 & 0.685 & 0.737 & 0.687 & 0.870 \\
\hline SYSQ4 & 0.739 & 0.731 & 0.742 & 0.708 & 0.741 & 0.728 & 0.868 \\
\hline SYSQ5 & 0.725 & 0.782 & 0.766 & 0.694 & 0.761 & 0.724 & 0.821 \\
\hline ACCM: Th & Acceptanc
\end{tabular}

ACCM: The Acceptance of Face Mask Mandate, INTU: Intention to Use, PTH: Perceived Threat, SATI: User Satisfaction

In Table 4, all the square roots of AVE have ensured convergent validity, which are greater than the correlation coefficients. Diagonal elements are the square roots of AVE.

\section{Structural Model}

Figure 3 and Table 5 display a path diagram, which explains the causal relationship of the proposed model. The results of the path analysis show that the higher the INFQ is, the more it will impact the intention to use and user satisfaction
Table 4. Fornell-Larcker criterion

\begin{tabular}{cccccccc}
\hline & ACCM & INFQ & INTU & PTH & SATI & SERQ & SYSQ \\
\hline ACCM & $\mathbf{0 . 9 3 2}$ & & & & & & \\
\hline INFQ & 0.767 & $\mathbf{0 . 8 6 8}$ & & & & & \\
\hline INTU & 0.798 & 0.839 & $\mathbf{0 . 9 3 3}$ & & & & \\
\hline PTH & 0.865 & 0.753 & 0.752 & $\mathbf{0 . 8 3 1}$ & & & \\
\hline SATI & 0.829 & 0.814 & 0.848 & 0.834 & - & & \\
\hline SERQ & 0.744 & 0.824 & 0.858 & 0.721 & 0.794 & $\mathbf{0 . 8 8 9}$ & \\
\hline SYSQ & 0.797 & 0.835 & 0.843 & 0.794 & 0.861 & 0.792 & $\mathbf{0 . 8 4 8}$ \\
\hline Diagonal elements (bold) are the square root of AVE between the \\
constructs and their measures. Off-diagonal elements are correlations \\
between constructs. User Satisfaction (SATI) are formative variables
\end{tabular}

Table 5. Results of path analysis

\begin{tabular}{lcccccc}
\hline \multicolumn{1}{c}{ Path } & $\begin{array}{c}\text { Path } \\
\text { Coefficient }\end{array}$ & S.D. & t & p-values & R2 & Q2 \\
\hline INFQ ->INTU & 0.177 & 0.062 & 2.831 & 0.005 & 0.834 & 0.712 \\
\hline SYSQ ->INTU & 0.196 & 0.061 & 3.223 & 0.001 & & \\
\hline SERQ ->INTU & 0.359 & 0.052 & 6.867 & $<0.001$ & & \\
\hline SATI ->INTU & 0.264 & 0.078 & 3.364 & 0.001 & & \\
\hline PTH ->INTU & -0.015 & 0.052 & 0.293 & 0.770 & & \\
\hline INFQ ->SATI & 0.202 & 0.075 & 2.679 & 0.007 & 0.784 & 0.591 \\
\hline SYSQ ->SATI & 0.522 & 0.071 & 7.319 & $<0.001$ & & \\
\hline SERQ ->SATI & 0.216 & 0.051 & 4.209 & $<0.001$ & & \\
\hline INTU ->ACCM & 0.251 & 0.065 & 3.840 & $<0.001$ & 0.804 & 0.691 \\
\hline SATI ->ACCM & 0.171 & 0.087 & 1.964 & 0.050 & & \\
\hline PTH ->ACCM & 0.534 & 0.062 & 8.647 & $<0.001$ & & \\
\hline
\end{tabular}

(path coefficient $=0.177$, $t$-value $=2.831$; path coefficient $=0.202$, t-value=2.679). This result supports $\mathrm{H} 1$ and $\mathrm{H} 2$. Besides, it clarifies that SYSQ can have direct positive impact on the intention to use (path coefficient $=0.196$, $t$-value=3.223) and user satisfaction (path coefficient $=0.522$, $t$-value $=7.319$ ), which supports $\mathrm{H} 3$ and $\mathrm{H} 4$. SERQ has a positive effect on the intention to use (path coefficient=0.359, t-value=6.867) and user satisfaction (path coefficient $=0.216$, $t$-value $=4.209$ ), which supports $\mathrm{H} 5$ and $\mathrm{H} 6$. User satisfaction is proved to influence positively on the intention to use (path coefficient $=0.264$, $t$ value=3.364), which supports $\mathrm{H} 7$. Finally, the intention to use 
Table 6. Hypotheses testing results

\begin{tabular}{llc}
\hline & Description & Supported? \\
\hline H1 & Information quality -> Intention to use & Yes \\
\hline H2 & System quality -> Intention to use & Yes \\
\hline H3 & Service quality -> Intention to use & Yes \\
\hline H4 & Information quality -> User satisfaction & Yes \\
\hline H5 & System quality -> User satisfaction & Yes \\
\hline H6 & Service quality -> User satisfaction & Yes \\
\hline H7 & User satisfaction -> Intention to use & Yes \\
\hline \multirow{2}{*}{ H8 } & $\begin{array}{l}\text { Intention to use -> The acceptance of face mask } \\
\text { mandate }\end{array}$ & Yes \\
\hline \multirow{2}{*}{ H9 } & $\begin{array}{l}\text { User satisfaction -> The acceptance of face mask } \\
\text { mandate }\end{array}$ & Yes \\
\hline H10 & Perceived threat -> Intention to use & No \\
\hline \multirow{2}{*}{ H11 } & $\begin{array}{l}\text { Perceived threat -> The acceptance of face mask } \\
\text { mandate }\end{array}$ & Yes \\
\hline & &
\end{tabular}

and user satisfaction are confirmed to have direct positive impact on the acceptance of the face mask mandate (path coefficient $=0.251$, $t$-value $=3.840$; path coefficient $=0.171$, $t$ value $=1.964$ ), and $\mathrm{H} 8$ and $\mathrm{H} 9$ are supported. Perceived threat is confirmed to have direct positive impact on the acceptance of the face mask mandate (path coefficient $=0.534$, $t$-value $=8.647$ ), but does not have impact on the intention to use (path coefficient $=-0.015$, $\mathrm{t}$-value $=0.293$ ). Therefore, $\mathrm{H} 11$ is supported, but $\mathrm{H} 10$ is not sup-ported. The results of hypotheses testing are summarized in Table 6.

\section{Importance-Performance Matrix Analysis}

As depicted in Figure 4, the IPMA of the intention to use the online face mask information system reveals that SERQ is the most important feature (total effects score $=0.421$, performance score $=77.987$ ) to predict users' intention to use the system. SYSQ has a relatively low importance score (0.363) and it has similar performance score (80.326) with SERQ. INFQ (0.253) is the least important factor. The effects of PTH on the intention is not statistically significant and can be ignored.

As depicted in Figure 5, the IPMA of the acceptance of face mask mandate reveals that perceived threat is the most important feature (total effects score $=0.603$, performance score $=75.222$ ) to predict people's acceptance of the mandate. The intention to use the online system and user satisfaction have a relatively low importance score $(0.302$ and 0.280$)$.

In these information system qualities, performance scores are similar. SYSQ $(0.226)$ has the highest important feature rating among all, and INFQ (0.122) are the least important factors.

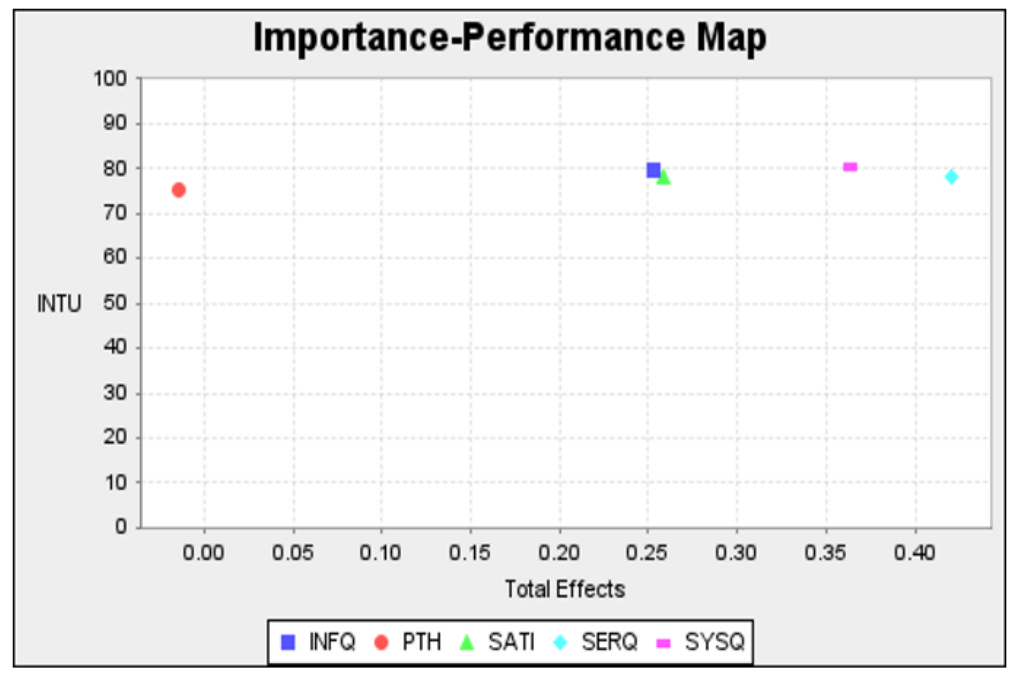

Figure 4. IPMA results for intention to use the online face mask information system

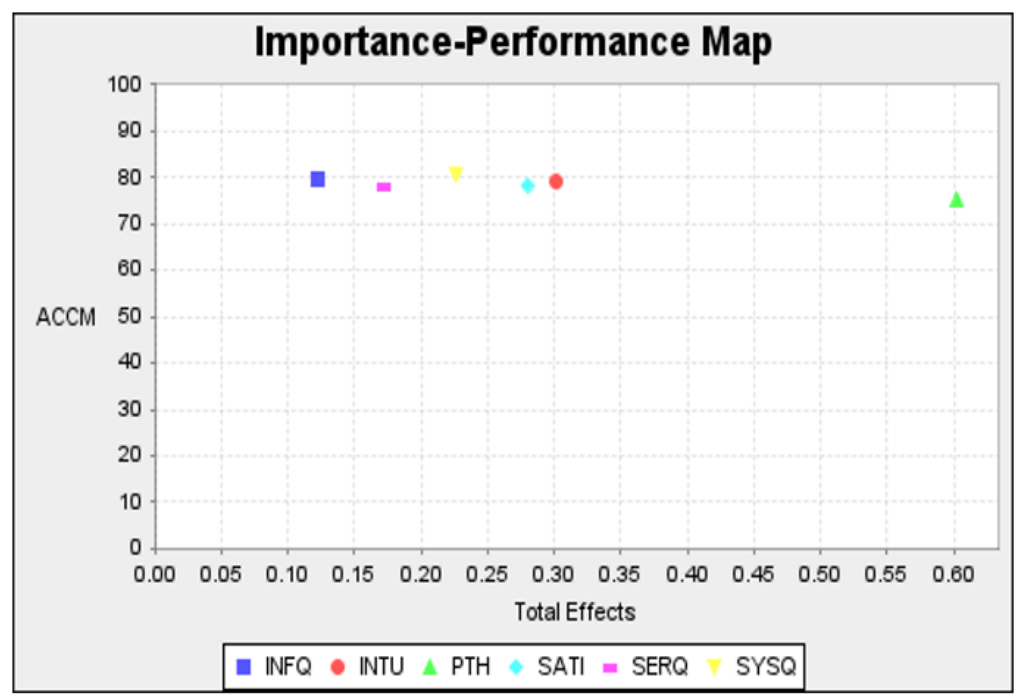

Figure 5. IPMA results for the acceptance of the face mask mandate in public places 


\section{DISCUSSION}

We constructed a research model by integrating the D\&M IS success model with the perceived threat of COVID-19 to investigate the factors affecting behavioral intention to use the online face mask information system to prevent the COVID-19 pandemic. In order to test the model, we proposed 11 hypotheses and conducted a survey.

\section{The Acceptance of Face Mask Mandate in Public Places}

According to the result of this study, the main reason that people accept the face mask regulation in public places is the perceived threat of COVID-19. When contracting an illness such as COVID-19, the consequence could be physical, economic, and social problems. That is, an individual would have adverse outcomes in regard to work, family life, social relations, or financial security. The study [23] pointed out that face mask wearing is the best way to reduce the risk or seriousness of COVID-19. It is important to enable people to have easy access to face masks, and therefore the development for a face mask rationing system is necessary.

The empirical results of this study indicate that the relationship between the intention to use, user satisfaction, and the acceptance of face mask mandate is significant. The more the people are willing to use the face mask online system, the more likely they will achieve the government's goal of making people accept the face mask mandate. Also, a higher degree of user satisfaction in the system will make people more willing to accept the face mask mandate. In the results of IPMA for the acceptance of the face mask mandate in public places, SYSQ and SERQ have high effect scores among these information system qualities.

SYSQ contains perceived usefulness and perceived ease of use. The design, layout, and sequencing of interface should make it easy for users to navigate. Difficulties in navigating online systems have been cited as a barrier for online orders, while well-designed navigation is noted to exert a positive effect on website sales. A good website interface will sustain people's interest in continuing to navigate the website and enhance people's experience to eventually increase the likelihood of use.

SERQ includes both online and offline support based on the information system success model [23]. In the case of Taiwan's mask-rationing system, the government should provide support for people to purchase face masks on the online system and pick up their orders at convenience stores with ease. Also, accurate and up-to-date information regarding face mask distribution should be provided as well.

\section{The Intention to Use Online System}

The empirical results also show that the connection between user satisfaction and the intention to use is significant. When users of the face mask online system are more satisfied, their loyalty or intention to use the system will increase [24].

The perceived threat of COVID-19 does not affect the intention to use the online system. The intention to use it can only be raised by improving the quality of the system.

In the results of IPMA for the intention to use the online face mask online system, SYSQ and SERQ have high effect scores among these information system qualities. It can be found that both SYSQ and SERQ play important roles in the intention to use the online system and the acceptance of the face mask mandate.

\section{Contribution}

Findings of this study have managerial implications for the public health department. With HBM [11], people would comply with epidemic prevention measures because of the fear of COVID-19. While the government's supply of information about the perceived susceptibility and seriousness of COVID-19 can increase people's intention to wear face masks, it may also increase people's anxiety and create unnecessary panic.

In addition, this study also demonstrates that to enhance the acceptance of epidemic control policies, the public health sector should establish information systems for epidemic prevention supplies, such as an online face mask ordering system.

The results of this study have empirically confirmed the significant impact of INFQ, SYSQ, and SERQ of the face mask information system on users' satisfaction and intention to use. This points out what public health managers should focus on in the establishment of an information system. Therefore, this study can provide guidance for the establishment of epidemic prevention supply systems and the promotion for public health policies in the future.

Managers of health information systems can evaluate a system from multiple aspects, and SYSQ and SERQ should be especially focused on since they have the most influence on user satisfaction. Therefore, by emphasizing these two factors, people's intention to re-use the system can be increased and their willingness to follow public health policies will also be enhanced as a result. In summary, the findings of this research can provide insights for the public health department in the establishment or evaluation of an online epidemic prevention supply system, such as an online face mask purchase system, or more recently, a vaccine scheduling system. Although we focus the application of the online face mask information system in Taiwan in this study, we believe that these findings regarding epidemic prevention information system could also provide insights for other countries in the future.

Funding: No funding source is reported for this study.

Declaration of interest: No conflict of interest is declared by author.

\section{REFERENCES}

1. Hanna TP, Evans GA, Booth CM. Cancer, COVID-19 and the precautionary principle: Prioritizing treatment during a global pandemic. Nat Rev Clin Oncol. 2020;17(5):268-70. https://doi.org/10.1038/s41571-020-0362-6 PMid:32242095 PMCid:PMC7117554

2. World Health Organization, WHO Coronavirus Disease (COVID-19) Dashboard, 2020. Available at: https://covid19.who.int/ (Accessed: 1 March 2021).

3. Taiwan Centers for Disease Control. Coronavirus disease 2019 (COVID-19), 2020. Available at: https://www.cdc. gov.tw/en/Disease/Sublndex/ (Accessed: 1 March 2021).

4. Summers J, Cheng HY, Lin HH, Barnard LT, Kvalsvig A, Wilson N, et al. Potential lessons from the Taiwan and New Zealand health responses to the COVID-19 pandemic. Lancet Reg Health West Pac. 2020;4;100044. https://doi.org/10.1016/j.lanwpc.2020.100044 PMid:34013216 PMCid:PMC7577184 
5. Yuan EJ, Hsu CA, Lee WC, Chen TJ, Chou LF, Hwang SJ. Where to buy face masks? Survey of applications using Taiwan's open data in the time of coronavirus disease 2019. J Chin Med Assoc. 2020;83(6):557-60. https://doi.org/ 10.1097/JCMA.0000000000000325 PMid:32304508 PMCid: PMC7199767

6. Hornik R, Kikut A, Jesch E, Woko C, Siegel L, Kim K. Association of COVID-19 misinformation with face mask wearing and social distancing in a nationally representative US sample. Health Commun. 2021:36(1):6-14. https://doi.org/10.1080/10410236.2020.1847437 PMid: 33225745

7. Rab S, Javaid M, Haleem A, Vaishya R. Face masks are new normal after COVID-19 pandemic. Diabetes Metab Syndr. 2020;14(6):1617-19. https://doi.org/10.1016/j.dsx.2020.08. 021 PMid:32889402 PMCid:PMC7451002

8. National Health Insurance Administration, Taiwan. The name-based rationing system for face masks, 2021. Availableat: https://www.nhi.gov.tw/english/Content_List. aspx?n=022B9D97EF66C076 (Accessed March 1, 2021)

9. Delone WH, McLean ER. The DeLone \& McLean model of information systems success: A ten-year update. J Manag Inf Syst. 2003;19(4):9-30. https://doi.org/10.1080/ 07421222.2003.11045748

10. Shim M, Jo HS. What quality factors matter in enhancing the perceived benefits of online health information sites? Application of the updated DeLone and McLean Information Systems Success Model. Int J Med Inform. 2020;137:104093. https://doi.org/10.1016/j.ijmedinf.2020. 104093 PMid:32078918

11. Rosenstock IM. The health belief model and preventive health behavior. Health Educ Monogr. 1974;2(4):354-86. https://doi.org/10.1177/109019817400200405

12. Chen W, Zheng Q, Liang C, Xie Y, Gu D. Factors Influencing college students' mental health promotion: The mediating effect of online mental health information seeking. Int J Environ Res Public Health. 2020;17(13):4783. https://doi.org/10.3390/ijerph17134783 PMid:32635176 PMCid:PMC7370060

13. Tilahun B, Fritz F. Modeling antecedents of electronic medical record system implementation success in lowresource set-ting hospitals. BMC Med Inform Decis Mak. 2015;15:61. https://doi.org/10.1186/s12911-015-0192-0 PMid:26231051 PMCid:PMC4522063
14. Lee SW, Sung HJ, Jeon HM. Determinants of continuous intention on food delivery apps: Extending UTAUT2 with information quality. Sustainability. 2019;11(11):3141. https://doi.org/10.3390/su11113141

15. Venkatesh V, Bala H. Technology acceptance model 3 and a research agenda on interventions. Decis. 2008;39(2):273315. https://doi.org/10.1111/j.1540-5915.2008.00192.x

16. Parasuraman A, Zeithaml VA, Berry LL. SERVQUAL: A multiple-item scale for measuring consumer perceptions of ser-vice quality. J Retail. 1988;64(1):12-40. Available at: https://search.proquest.com/scholarly-journals/servqualmultiple-item-scale-measuring-

consumer/docview/228609374/se-2?accountid=12957

17. Chen HJ. Linking employees' e-learning system use to their overall job outcomes: An empirical study based on the IS success model. Comput Educ. 2010;55(4):1628-39. https://doi.org/10.1016/j.compedu.2010.07.005

18. Graf AS, Carney AK. Ageism as a modifying influence on COVID-19 health beliefs and intention to social distance. J Aging Health. 2021. https://doi.org/10.1177/08982643219 97004 PMid:33625259 PMCid:PMC8685589

19. Ringle CM, Wende S, Becker JM. SmartPLS 3. Bönningstedt: SmartPLS, 2015. Available at: http://www.smartpls.com

20. Chin WW. Commentary: Issues and opinion on structural equation modeling. MIS Q. 1998; 22(1):vii-xvi. https://www.jstor.org/stable/249674

21. Hair JF, Black WC, Babin BJ, Anderson RE, Tatham RL. Multivariate data analysis. New Jersey: Prentice-Hall, 2006.

22. Hair JF, Hult GTM, Ringle C, Sarstedt M. A primer on partial least squares structural equation modeling (PLS-SEM). Thousand Oaks, CA: SAGE, 2014. https://doi.org/10.1108/ EBR-10-2013-0128

23. Liang M, Gao L, Cheng C, Zhou Q, Uy JP, Heiner K, Sun C. Efficacy of face mask in preventing respiratory virus transmission: A systematic review and meta-analysis. Travel Med Infect Dis. 2020;36:101751. https://doi.org/10.1016/ j.tmaid.2020.101751 PMid:32473312 PMCid:PMC7253999

24. Fornell C, Johnson MD, Anderson EW, Cha J, Bryant BE. The American customer satisfaction index: Nature, purpose and findings. J Mark. 1996;60(4):7-18. https://doi.org/ $10.1177 / 002224299606000403$ 